\title{
Preparation of carbon fiber from water hyacinth liquid tar
}

\author{
Soegiarto Adi Soenjaya • Nova Handoyo • \\ Felycia Edi Soetaredjo • Artik Elisa Angkawijaya • \\ Yi-Hsu Ju $\cdot$ Suryadi Ismadji
}

Received: 22 May 2014/ Accepted: 17 November 2014/Published online: 29 November 2014

(C) The Author(s) 2014. This article is published with open access at Springerlink.com

\begin{abstract}
Elemental analysis of water hyacinth liquid tar indicated that it contains significant amount of oxygen atom. GC-MS analysis shows that the water hyacinth liquid tar is a suitable precursor for the preparation of intermediate material for carbon fiber due to high content of phenolic compounds. The carbonization of water hyacinth resin was carried out at $900{ }^{\circ} \mathrm{C}$ and the yield of the maximum total yield of carbon fiber was $29 \%$. The carbon fiber was characterized using SEM, and XRD methods, while the FTIR analysis was conducted to qualitatively verify the surface functional groups of water hyacinth tar and resin. The XRD analysis revealed that the carbon fiber is non-graphitic in nature. The pyrolysis temperature did not have any effect on the properties of the carbon fibers. The axial modulus and the tensile strength of carbon fibers produced from water hyacinth tar are around $42 \mathrm{GPa}$ and $600 \mathrm{MPa}$, respectively. These properties are comparable to the commercial carbon fiber.
\end{abstract}

Keywords Water hyacinth · Carbon fiber .

Liquid tar $\cdot$ Resin

S. A. Soenjaya · N. Handoyo · F. Edi Soetaredjo $(\bowtie)$.

S. Ismadji

Department of Chemical Engineering, Widya Mandala Surabaya Catholic University, Kalijudan 37, Surabaya 60114, Indonesia

e-mail: felyciae@yahoo.com

A. E. Angkawijaya · Y.-H. Ju

Department of Chemical Engineering, National Taiwan

University of Science and Technology, 43, sec. 4 Keelung Rd.,

Taipei 106, Taiwan

\section{Introduction}

Carbon fiber has been in use as a precursor for the preparation of composite materials (carbon fiber-reinforced polymer) for various applications. Currently, the commercially available carbon fibers are made mostly from organic polymers such as polyacrylonitrile (PAN), rayon or petroleum pitches. The major drawback of commercial carbon fibers from those organic polymers as the precursor is in the high cost of precursors. Almost half of carbon fiber production costs are associated with precursors [5]. In the recent years, many studies have been carried out to find out renewable polymers as the precursors for carbon fiber production $[5,7,12]$. These renewable polymers have several advantages compared to those PAN or petroleum pitches since they are renewable, low in cost, and abundantly available for large scale production.

Lignin is a potential precursor for the preparation of carbon fiber. However, the production of carbon fiber using lignin as the feed stocks is a challenging process especially in the melt-spinning process. It has complex chemical structure and it is difficult to recover in a clean and pure form [6]. In the melt-spinning process high-purity lignin is required to obtain proper mechanical properties of the carbon fiber. Details of the history of carbon fiber from the lignin and modification of lignin to improve the mechanical properties of the carbon fiber have been summarized by Luo et al. [6].

The possibility of using liquid tar as the new precursor for the preparation of carbon fiber has been explored by Qiao et al. [10]. The idea of utilizing liquid tar obtained from the pyrolysis of biomass inspired from commercial production of phenolic resin from phenol and formaldehyde. In the manufacture of commercial phenolic resin, the polymerization reaction of phenols with formaldehyde is 
conducted in the presence of the acid catalyst such as hydrochloric acid or sulfuric acid. The major components in liquid tar of biomass are phenols and its derivatives; therefore, it can be employed as the carbon source or precursor for carbon fiber.

In the present study, carbon fiber was prepared from water hyacinth tar. The water hyacinth tar-based resins were prepared by polymerization of tar in formaldehyde using hydrochloric acid as the catalyst. The resulting resins were then processed into carbon fiber. More competitive carbon fiber precursor from the renewable resource as well as the simple and practical process has been obtained in the study.

\section{Experimental}

\section{Materials}

Water hyacinth as feedstock in this study was collected from a river in Surabaya, East Java, Indonesia. Prior to the size reduction, the water hyacinth was dried under the sun to reduce its moisture content. Subsequently, dried water hyacinth was ground in a Philips HR2115 grinder to reduce its particle size. The dried water hyacinth powder was then kept in a desiccator for further use. The proximate analysis of the dried water hyacinth powder is given in Table 1 . The proximate analysis was conducted according to the ASTM procedures (ASTM D4442-07 for moisture content, ASTM E1755-01 for ash content, and ASTM D3175-11 for volatile matter content). The fixed carbon content was calculated by the following equation:

$$
\begin{aligned}
\% \text { Fixed carbon }= & 100 \%-\% \text { of }(\text { moisture }+ \text { ash } \\
& + \text { volatile matter })
\end{aligned}
$$

Pyrolysis experiment

The pyrolysis of water hyacinth was conducted in a Thermolyne F21130-26 tubular furnace. The pyrolysis experiments were carried out at $450,500,550$, and $600{ }^{\circ} \mathrm{C}$ with a heating rate of $60{ }^{\circ} \mathrm{C} / \mathrm{min} .10 \mathrm{~g}$ of water hyacinth powder was introduced into the tubular furnace reactor and subsequently the tubular furnace was tightly closed and sealed to prevent any leaking. In order to prevent oxidation or combustion during the pyrolysis process and to maintain

Table 1 Proximate analysis of water hyacinth

\begin{tabular}{lc}
\hline Analysis & Amount (\%) \\
\hline Moisture content & 11.70 \\
Volatile matters & 67.27 \\
Total ash content & 2.29 \\
Fixed carbon & 18.74 \\
\hline
\end{tabular}

the inert condition, nitrogen gas was introduced to the system at a flow rate of $3 \mathrm{~L} / \mathrm{min}$. The tubular furnace reactor was then heated at a rate of $60{ }^{\circ} \mathrm{C} / \mathrm{min}$ from room temperature to desired temperatures $(450,500,550$, and $600{ }^{\circ} \mathrm{C}$ ) and held isothermally for $2 \mathrm{~h}$. During the pyrolysis process, the gases and vapors products generated from the thermal cracking of biomass were passed into double-stage condensers which operated at $4{ }^{\circ} \mathrm{C}$. In the condensers, the condensable vapors were condensed into liquid and collected in measuring cylinder as liquid tar. The non-condensable gases together with the carrier gas were passed to a flow meter where the volume of exit gases was recorded. The yield of char and bio-oil was determined by weighing the mass of both products using an analytical balance (Precisa 3000D).

\section{Liquid tar characterization}

Liquid tars obtained from the pyrolysis process were characterized using Agilent 6890N Gas Chromatography equipped with an Agilent Inert XL Mass Spectrometry detector. Capillary column used was Varian CP9154 $60 \mathrm{~m}$ $\times 0.25 \mathrm{~mm} \times 250 \mu \mathrm{m}$ with helium as the carrier. Acetone was used as the solvent for diluting the water hyacinth tar (500:1). Identification of the chemical constituents in liquid tar was conducted by comparing the mass spectra patterns of the sample with the National Institute of Standards and Technology (NIST) database.

\section{Polymerization of liquid tar into resin}

The polymerization of water hyacinth tar into resin was carried out as follows: $50 \mathrm{~g}$ of water hyacinth tar and $50 \mathrm{~g}$ of an aqueous $37 \%$ formaldehyde solution were introduced to $250-\mathrm{mL}$ flask. Subsequently, $10 \%$ of oxalic acid (as catalyst) was added to the mixture, and heated at $90{ }^{\circ} \mathrm{C}$ for $60 \mathrm{~min}$ under constant stirring at $500 \mathrm{rpm}$. After $60 \mathrm{~min}, 10 \% \mathrm{HCl}$ solution was added to the mixture and also heated at $90{ }^{\circ} \mathrm{C}$ for 35 min under constant stirring at $500 \mathrm{rpm}$. After completion of the reaction, the water was removed from the mixture and the water hyacinth resin was obtained after drying.

Preparation of carbon fiber from water hyacinth resin

The water hyacinth resin was spun at $180{ }^{\circ} \mathrm{C}$ at a winding rate of $250 \mathrm{rpm}$. Subsequently, it was stabilized at temperature of $200{ }^{\circ} \mathrm{C}$ for $1 \mathrm{~h}$, and carbonized at $900{ }^{\circ} \mathrm{C}$ at a slow heating rate $\left(1{ }^{\circ} \mathrm{C} / \mathrm{min}\right)$ for $1 \mathrm{~h}$ under constant nitrogen flow with the flow rate of $3 \mathrm{~L} / \mathrm{min}$. The resulting carbon fiber was characterized using SEM, and XRD, while the FTIR analysis was conducted to qualitatively verify the surface functional groups of water hyacinth tar and resin. 
The surface morphology of carbon fiber from water hyacinth was visualized using a field emission scanning electron microscopy JEOL JSM-6300F. Prior to analysis, the samples were coated with a thin layer of platinum using an Eiko IB-5 sputter-coater operated at $6 \mathrm{~mA}$ for $3 \mathrm{~min}$ in argon atmosphere. The coated samples were then placed in the SEM specimen chamber and scanned at an accelerating voltage of $10 \mathrm{kV}$.

The X-ray scattering data of carbon fibers were obtained on a Philips PANalytical X'Pert X-ray diffractometer, and the crystallographic parameter $\left(d_{002}\right)$ was obtained according to the JSPS (Japan Society for the Promotion of Science) procedure [10]. The powder diffractograms of the specimens were acquired at $40 \mathrm{kV}$ and $30 \mathrm{~mA}$ from 2-theta of $5^{\circ}$ to $90^{\circ}$ with a scanning speed of $1 \% \mathrm{~min}$. The radiation source was Ni-filtered $\mathrm{Cu} \mathrm{K} \alpha_{1} \quad(\lambda=0.15405 \mathrm{~nm}$ and graphite monochromator).

The FTIR analysis of water hyacinth tar and resin was conducted on a Shimadzu FTIR 8400S spectrometer using $\mathrm{KBr}$ as a binder. FT IR spectrum of tar was measured by painting tar on the surface of a $\mathrm{KBr}$ pellet. The spectra data of samples were collected within 4,000-500/cm in transmission mode. Data processing includes baseline adjustment, normalization, and spectral smoothing was performed using IRsolution software package (version 1.21) available within the instrument.

The tensile strength and axial modulus of carbon fiber were measured in INSTRON 1195 machine. The experimental procedure consists of the sample preparation, the testing of materials, the determination of system compliance, and calculation of tensile strength and axial modulus. Details about the procedure can be found in [3].

\section{Results and discussion}

The characteristics of water hyacinth tar

The properties of water hyacinth tar obtained at various pyrolysis temperatures are shown in Table 2. From this table it can be seen that all of the tar obtained from different temperatures possess very high oxygen content. Water hyacinth tar is very complex mixtures of different

Table 2 Elemental analysis of water hyacinth tar

\begin{tabular}{|c|c|c|c|c|c|c|}
\hline \multirow{2}{*}{$\begin{array}{l}\text { Pyrolysis } \\
\text { temperature } \\
\left({ }^{\circ} \mathrm{C}\right)\end{array}$} & \multicolumn{4}{|c|}{ Elemental analysis (\% wt) } & \multirow{2}{*}{$\begin{array}{l}\mathrm{C} / \mathrm{H} \\
\text { (atomic } \\
\text { ratio) }\end{array}$} & \multirow{2}{*}{$\begin{array}{l}\mathrm{C} / \mathrm{O} \\
\text { (atomic } \\
\text { ratio) }\end{array}$} \\
\hline & $\mathrm{C}$ & $\mathrm{H}$ & $\mathrm{N}$ & $\mathrm{O}$ & & \\
\hline 450 & 63.23 & 7.31 & 0.18 & 29.28 & 0.72 & 2.88 \\
\hline 500 & 62.74 & 7.99 & 0.17 & 29.10 & 0.65 & 2.87 \\
\hline 550 & 61.71 & 6.92 & 0.18 & 31.19 & 0.74 & 2.63 \\
\hline 600 & 62.04 & 7.14 & 0.14 & 30.68 & 0.72 & 2.70 \\
\hline
\end{tabular}

chemical species derived from depolymerization and fragmentation of water hyacinth main components (lignin, cellulose, and hemicellulose). The chemical species in the liquid tar are organic compounds and cover a wide range of molecular weights [2]. The organic compounds in liquid tar consist of acids, phenols, esters, aldehyde, ketones, alcohols, hydrocarbons, and other organic compounds. The chemical compositions of the water hyacinth tar are given in Table 3, while the GC-MS spectrum is depicted in Fig. 1. Due to the very complex reaction occurring during the pyrolysis process, the composition of organic compounds in water hyacinth tar does not depend on the temperature as indicated in Table 3. Similar results were also obtained by other researchers [9, 11]. High content of phenolic compounds indicates that the water hyacinth tar is a suitable raw material for carbon fiber production. Phenolic compounds in water hyacinth tar originated from the thermal decomposition of lignin during the pyrolysis process, which is a complex aromatic structure composed by substitution of phenyl propane units, linked by hydroxy and methoxy groups [1, 2].

The yield of pyrolysis products (tar, char and gas) at various temperatures is summarized in Table 4. The yield of tar increases with the increase of temperature (from 450 to $550{ }^{\circ} \mathrm{C}$ ); however, further increase of temperature results in the decrease of tar as seen in Table 4. The decrease of the tar is due to the secondary cracking reaction; the tar decomposed into smaller compounds in the form of gases $\left(\mathrm{CO}_{2}, \mathrm{CO}, \mathrm{CH}_{4}, \mathrm{H}_{2}\right.$, etc. $)$.

Water hyacinth tar into resin

The polymerization reaction between water hyacinth tar and formaldehyde in the presence of acid catalyst was conducted at $90{ }^{\circ} \mathrm{C}$ in batch mode under constant stirring. The maximum yield of resin was $63 \%$ (Table 5). The yield of resin

Table 3 Chemical composition of water hyacinth tar

\begin{tabular}{lrrrr}
\hline Compounds (wt\%, dry basis) & \multicolumn{5}{c}{ Temperature $\left({ }^{\circ} \mathrm{C}\right)$} \\
\cline { 2 - 5 } & \multicolumn{1}{c}{450} & \multicolumn{1}{c}{500} & 550 & 600 \\
\hline Acids & 17.05 & 19.44 & 25.44 & 18.09 \\
Alcohols & 1.98 & 2.41 & 3.77 & 2.11 \\
Aldehydes and ketones & 8.77 & 10.33 & 9.74 & 12.04 \\
Esters & 9.26 & 6.84 & 9.45 & 8.77 \\
Ethers & 4.81 & 6.02 & 3.48 & 5.63 \\
Phenols & 20.74 & 18.21 & 22.45 & 21.43 \\
Furans & 5.04 & 6.79 & 5.44 & 5.44 \\
Hydrocarbons and its derivative & 1.32 & 0.92 & 1.24 & 3.27 \\
Nitrogen compounds & 0.71 & 0.64 & 0.71 & 0.79 \\
Oxygenated cyclic compounds & 3.06 & 4.02 & 3.28 & 3.88 \\
Unknowns & 27.26 & 24.38 & 15.00 & 18.55 \\
\hline
\end{tabular}




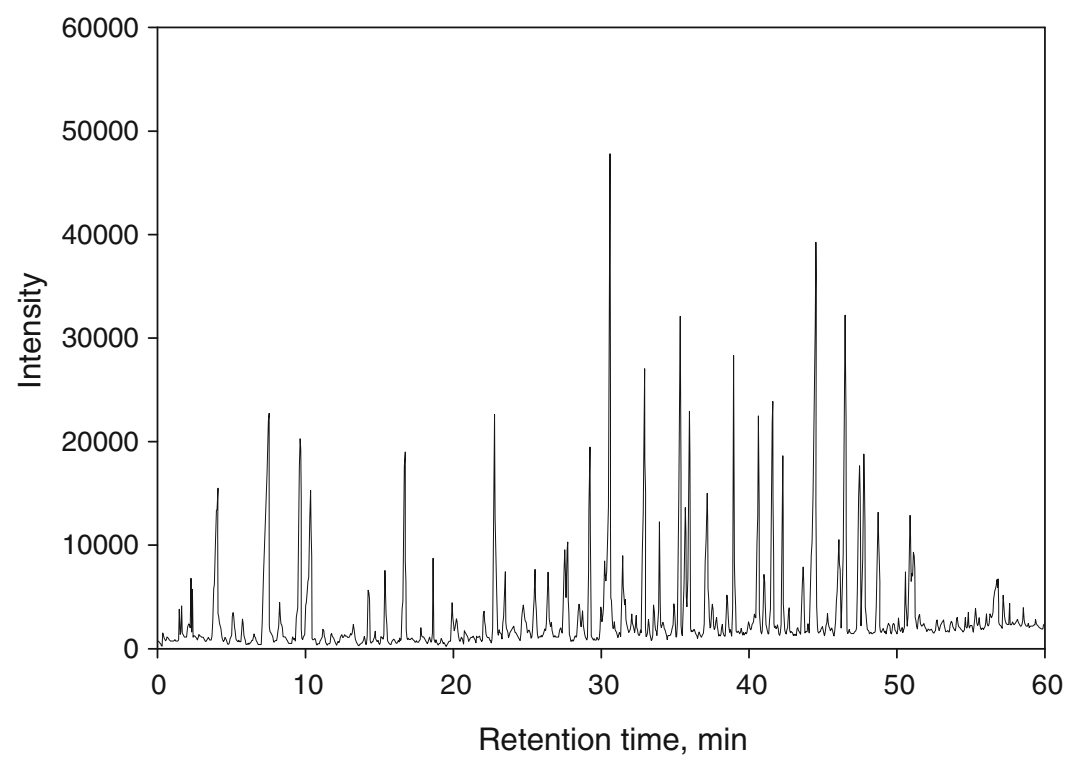

$\begin{array}{cllll}\begin{array}{c}\text { Ret. time } \\ 1.48\end{array} & \text { Acompound } & & & \\ 1.62 & \text { Methyl acetate } & 14.77 & \text { Acetic acid } & 31.52 \text { Aniline } \\ 2.27 & \text { Methanol } & 15.39 & \text { 3-Penten-2-one } & 32.98 \text { Pentanoic acid } \\ 2.39 & \text { Furan, 3-methyl- } & 16.76 & \text { Cyclopentanone } & 33.92 \text { Cresol } \\ 4.12 & \text { 2-Hexene } & 17.88 & \text { Acetic anhydride } & 35.33 \text { Dimethylphenol } \\ 5.22 & \text { Vinyl acetate } & 18.64 & \text { Propanoic acid } & 35.95 \text { Guaiacol } \\ 5.83 & \text { Ethanol } & 20.04 & \text { 2-Propenyl butanoate } & 37.18 \text { Phenylacetone } \\ 6.59 & \text { 2-Butanone } & 20.26 & \text { Cyclooctane } & 38.84 \text { Ethylphenol } \\ 7.64 & \text { Butane, 1-ethoxy- } & 20.81 & \text { Cyclopentenone } & 40.72 \text { 2-Formylpyrrol } \\ 8.27 & \text { Propane, 1-ethoxy-2-methyl- } & 22.82 & \text { Trimethylphenol } & 41.65 \text { Dibutylformamide } \\ 9.65 & \text { Formic acid } & 23.57 & \text { Furfural } & 42.28 \text { Catechol, 4-ethyl- } \\ 10.28 & \text { 2-Pentanone } & 24.82 & \text { Butanoic acid } & 43.68 \text { Cynamaldehyde } \\ 11.16 & \text { 2-Propenyl acetate } & 25.57 & \text { Isocrotonic acid } & 44.54 \text { Eugenol } \\ 11.66 & \text { Methyl butanoate } & 27.86 & \text { Octanal } & 46.57 \text { Syringol } \\ 13.28 & \text { Vinyl butanoate } & 28.58 & \text { Decane } & 47.82 \text { Isoeugenol } \\ 14.27 & \text { 2-Butenal } & 30.64 & \text { Phenol } & 48.76 \text { Vainillin }\end{array}$

Fig. 1 GC-MS spectrum of water hyacinth tar

Table 4 The yield of pyrolysis products at various temperatures

\begin{tabular}{lllll}
\hline Product (wt\%) & \multicolumn{4}{l}{ Temperature $\left({ }^{\circ} \mathrm{C}\right)$} \\
\cline { 2 - 5 } & 450 & 500 & 550 & 600 \\
\hline Tar & 30.4 & 40.2 & 47.3 & 41.2 \\
Char & 50.9 & 33.9 & 20.6 & 20.3 \\
Gas & 18.7 & 25.9 & 32.1 & 38.5 \\
\hline
\end{tabular}

was higher than phenol content in the liquid tar, possibly due to the presence of other groups similar to phenols that are easier to access and reacted with formaldehyde to form the resin, resulting in higher yield of resin. This result is lower than those obtained by Qiao et al. [10]. In their study, the polymerization of wood and bamboo tars with formaldehyde provided resins with yields of 72 and $80 \%$, respectively [10]. Wood and bamboo contain higher lignin than water hyacinth; therefore, its liquid tar contains higher phenols compounds and the polymerization of these tars produced more resins. Mitsunaga and coworkers reported the reactivity of phenolic compounds with formaldehyde using ab initio methods at the RHF/6-31+G level of theory using the CHelpG method [8]. CHelpG method is an atomic charge calculation scheme in which atomic charges are fitted to reproduce the molecular electrostatic potential (MESP) at a number of points around the molecule.

The assignment of characteristic FTIR spectra of water hyacinth tar and resin to functional groups are in Table 6. FTIR spectrum of water hyacinth tar indicates that this sample contains different kinds of organic compounds and different functional groups as well (Fig. 2). These functional groups in general are similar to the functional groups of liquid tar from oak, pine, and bamboo [4]. The FTIR spectrum (Fig. 2) of water hyacinth resin indicates abundant functional groups also present in the resin, especially- 
Table 5 Yield of resin and carbon fibers

\begin{tabular}{llllll}
\hline $\begin{array}{l}\text { Pyrolysis } \\
\text { temperature }\left({ }^{\circ} \mathrm{C}\right)\end{array}$ & $\begin{array}{l}\text { Yield of } \\
\operatorname{tar}(\%)\end{array}$ & $\begin{array}{l}\text { Yield of } \\
\text { resin }(\%)\end{array}$ & $\begin{array}{l}\text { Stabilization } \\
\text { yield }(\%)\end{array}$ & $\begin{array}{l}\text { Carbonization } \\
\text { yield }(\%)\end{array}$ & $\begin{array}{l}\text { Total yield of } \\
\text { carbon fiber }(\%)\end{array}$ \\
\hline 450 & 30.4 & 57.8 & 90.5 & 49.2 & 25.7 \\
500 & 40.2 & 59.9 & 89.1 & 48.5 & 25.9 \\
550 & 47.3 & 63.0 & 90.2 & 51.0 & 29.0 \\
600 & 41.2 & 60.2 & 87.8 & 50.5 & 26.7 \\
\hline
\end{tabular}

Table 6 Functional group analysis of water hyacinth tar and resin in FTIR spectra

\begin{tabular}{|c|c|c|}
\hline \multirow[t]{2}{*}{ Functional group } & \multicolumn{2}{|c|}{ Wavenumber $\left(\mathrm{cm}^{-1}\right)$} \\
\hline & $\begin{array}{l}\text { Water } \\
\text { hyacinth tar }\end{array}$ & $\begin{array}{l}\text { Water hyacinth } \\
\text { resin }\end{array}$ \\
\hline $\mathrm{O}-\mathrm{H}$ stretching & 3,432 & $3,600-3,200$ \\
\hline $\mathrm{C}-\mathrm{H}$ stretching & $2,968-2,870$ & $2,967-2,872$ \\
\hline $\begin{array}{l}\mathrm{C}=\mathrm{O} \text { stretching of carbonyl } \\
\text { structure }\end{array}$ & 1,704 & 1,735 \\
\hline Aromatic ring vibration & $1,621,1,513$ & $1,617,1,512$ \\
\hline $\begin{array}{l}\mathrm{C}-\mathrm{H} \text { deformation vibrations } \\
\text { (asymmetric) }\end{array}$ & $1,452,1,370$ & $1,453,1,377$ \\
\hline phenolic $\mathrm{OH}$ and ether groups & $1,221,1,265$ & $1,211,1,267$ \\
\hline $\begin{array}{l}\mathrm{C}-\mathrm{O} \text { stretching of diphenyl ether } \\
\text { structure }\end{array}$ & 1,255 & 1,248 \\
\hline $\mathrm{C}-\mathrm{O}$ stretching of phenol group & 1,231 & 1,232 \\
\hline
\end{tabular}

OH stretching group $(3,600-3,200 / \mathrm{cm})$. The phenolic $\mathrm{OH}$ and ether groups were also observed at 1,211 and 1,267/ $\mathrm{cm}$.
Carbon fiber and its characterization

The stabilization of water hyacinth resin was conducted at $200{ }^{\circ} \mathrm{C}$ for $1 \mathrm{~h}$. During stabilization, some of the small molecular weight volatile components evaporated and result in the decrease of resin weight about $15 \%$. The carbonization of the water hyacinth resin was conducted at low heating rate $\left(1^{\circ} \mathrm{C} / \mathrm{min}\right)$ to avoid the deformation and melting of the stabilized resin. During the carbonization the depolymerization and cracking of the resin occurred and the yield of $44 \%$ of carbon fiber was obtained after the carbonization process was completed.

The morphologies of carbon fiber derived from water hyacinth are given in Fig. 3. Smooth surface and almost uniform size of the fiber was observed in Fig. 3. The diameter of the fiber obtained in this study is around $10 \mu \mathrm{m}$, similar to the commercially available carbon fiber.

Carbon fiber produced from water hyacinth was characterized using X-ray diffraction. The interlayer spacing $\left(d_{002}\right)$ of the carbon was calculated using the Bragg equation:
Fig. 2 FTIR spectra of water hyacinth tar and its resin

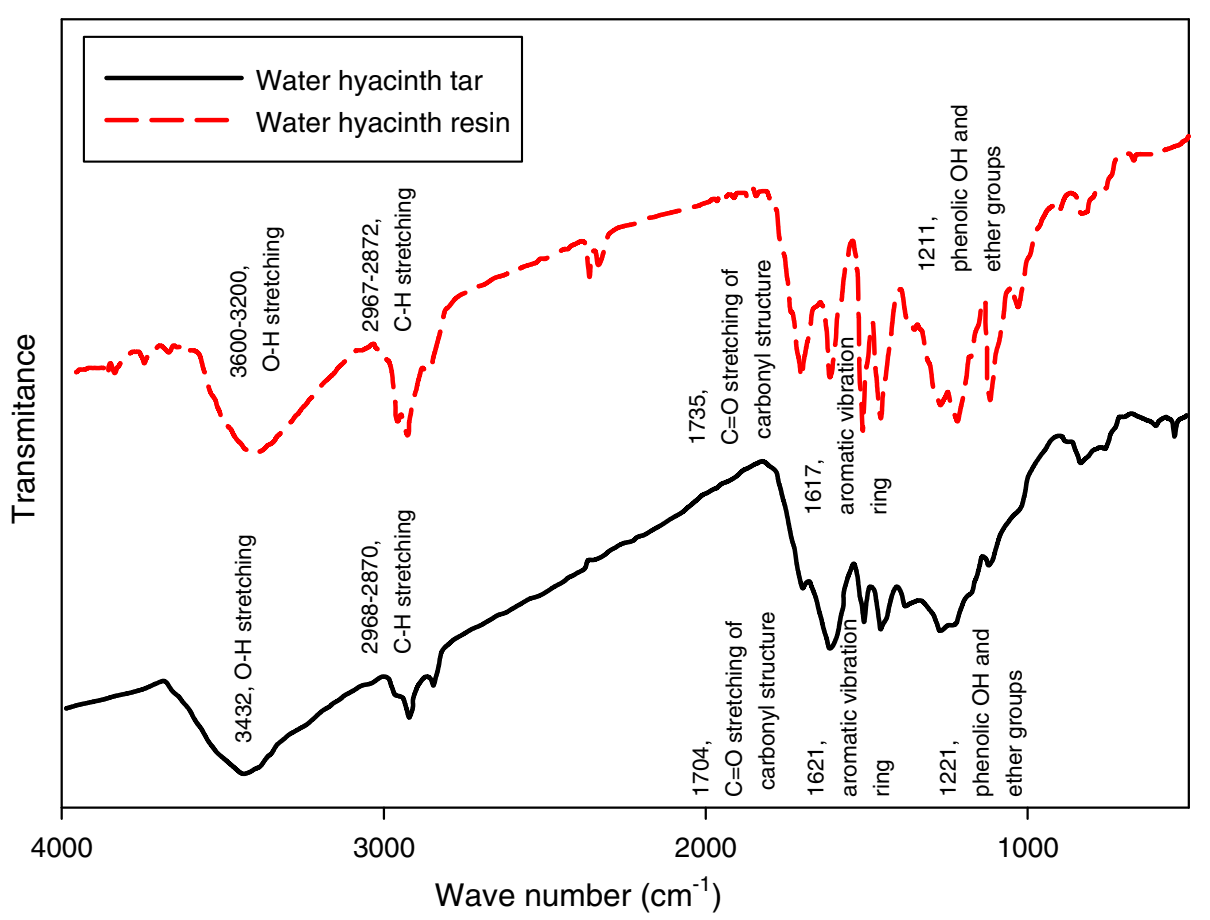



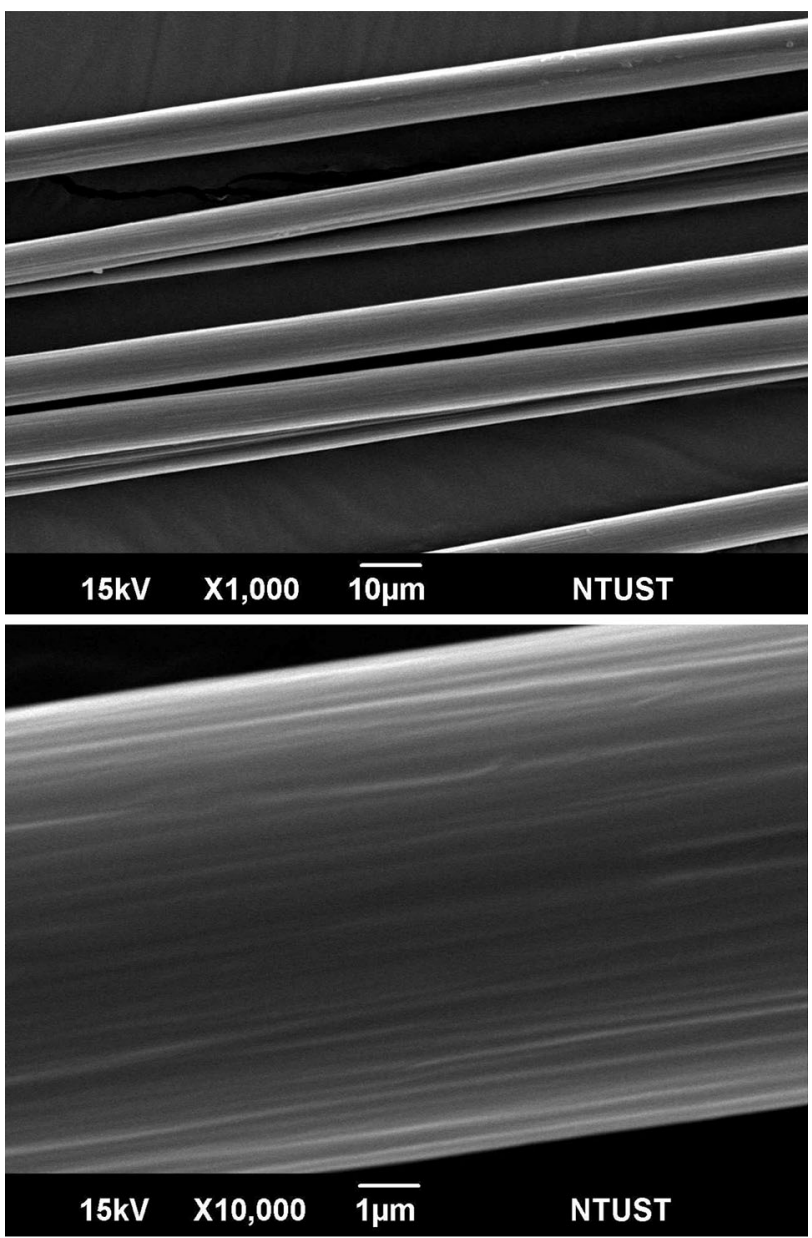

Fig. 3 The SEM analysis of carbon fiber prepared from water hyacinth liquid tar in different magnification

$d=\frac{\lambda}{2 \sin \theta}$,

where $\lambda$ is the $\mathrm{X}$-ray wavelength and $\theta$ is the scattering angle for the peak position. The diffractogram of the carbon fiber is depicted in Fig. 4. The value obtained for interlayer spacing $\left(d_{002}\right)$ for carbon fiber produced from water hyacinth was $0.358 \mathrm{~nm}$, this value was higher than the ideal graphite having $d_{002}$ value as $0.335 \mathrm{~nm}$ indicating the carbon fiber has non-graphitic nature (standard JCPDS 41-1478 is also given in Fig. 4).

The axial modulus and tensile strength of carbon fibers produced using water hyacinth tar as precursor is given in Table 7. From this table it can be seen that the pyrolysis temperature does not have any influence on the performance of carbon fibers. The axial modulus and the tensile strength of carbon fibers produced from water hyacinth tar are around $42 \mathrm{GPa}$ and $600 \mathrm{MPa}$, respectively. These values are comparable with carbon fiber produced from bamboo tar and commercially available carbon fibers from pitch tar [10].

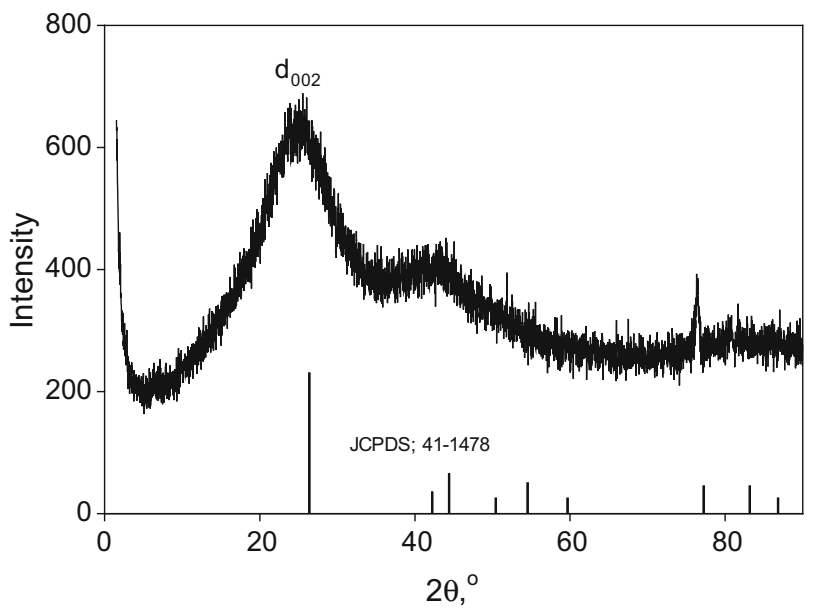

Fig. 4 The XRD pattern of the carbon fiber prepared from water hyacinth liquid tar

Table 7 Axial modulus and tensile strength of carbon fibers

\begin{tabular}{lll}
\hline $\begin{array}{l}\text { Pyrolysis } \\
\text { temperature }\left({ }^{\circ} \mathrm{C}\right)\end{array}$ & $\begin{array}{l}\text { Axial modulus } \\
(\mathrm{GPa})\end{array}$ & $\begin{array}{l}\text { Tensile strength } \\
(\mathrm{MPa})\end{array}$ \\
\hline 450 & 41.9 & 589.5 \\
500 & 42.4 & 604.4 \\
550 & 42.1 & 600.7 \\
600 & 41.8 & 584.3 \\
\hline
\end{tabular}

\section{Conclusion}

The analysis of chemical composition of the water hyacinth liquid tar reveals that this liquid contains significant amounts of phenolic compounds. High content of phenolic compounds indicates that the water hyacinth tar is a suitable raw material for carbon fiber production. The preparation of resin was conducted by polymerization of liquid tar with formaldehyde in the presence of acid catalyst. The maximum yield of resin was $63 \%$. In the present study, the carbon fiber was successfully prepared from water hyacinth liquid tar with uniform diameter.

Open Access This article is distributed under the terms of the Creative Commons Attribution License which permits any use, distribution, and reproduction in any medium, provided the original author(s) and the source are credited.

\section{References}

1. Argyropoulos DS, Sadeghifar H, Cui CZ, Sen S (2014) Synthesis and characterization of poly(arylene ether sulfone) kraft lignin heat stable copolymers. ACS Sustain Chem Eng 2:264-271

2. Bertero M, de la Puente G, Sedran U (2012) Fuels from bio-oils: Bio-oil production from different residual sources, characterization and thermal conditioning. Fuel 95:263-271 
3. Ilankeeran PK, Mohite PM, Kamle S (2012) Axial tensile testing of single fibers. Mod Mech Eng 2:151-156

4. Ku CS, Mun SP (2006) Characterization of pyrolysis tar derived from lignocellulosic biomass. J Ind Eng Chem 12:853-861

5. Liu W, Zhao G (2012) Effect of temperature and time on the microstructure and surface functional groups of activated carbon fibers prepared from liquefied wood. Bioresources 7:5552-5567

6. Luo J, Genco J, Cole B, Fort R (2011) Lignin recovered from the near neutral hemicellulose extraction process as a precursor for carbon fiber. Bioresources 6:4566-4593

7. Li D, Ma X (2013) Preparation and characterization of activated carbon fibers from liquefied wood. Cellulose 20:1649-1656

8. Mitsunaga T, Conner AH, Hill CG Jr (2002) Predicting the reactivity of phenolic compounds with formaldehyde. II. Continuation of an ab initio study. J Appl Polym Sci 86:135-140
9. Ong LK, Kurniawan A, Lin CX, Ju YH, Ismadji S (2013) Bio-oil from cassava peel: a potential renewable energy source. Biores Technol 145:157-161

10. Qiao WM, Huda M, Song Y, Yoon SH, Korai Y, Mochida I, Katou O, Hayashi H, Kawamoto K (2005) Carbon fibers and films based on biomass resins. Energy Fuels 19:2576-2582

11. Weerachanchai $P$, Tangsathitkulchai $C$, Tangsathitkulchai $M$ (2011) Characterization of products from slow pyrolysis of palm kernel cake and cassava pulp residue. Korean J Chem Eng 28:2262-2274

12. Zheng J, Zhao Q, Ye Z (2014) Preparation and characterization of activated carbon fiber (ACF) from cotton woven waste. Appl Surf Sci 299:86-91 